\title{
Article \\ Degradation of CP4-EPSPS with a Psychrophilic Bacterium Stenotrophomonas maltophilia 780
}

\author{
Yanhong Peng ${ }^{1}$, Wencong He ${ }^{1}$, Yunjing $\mathrm{Li}^{2}{ }^{2}$ Lu Liu ${ }^{1}$, Binyang Deng ${ }^{1}$, Guangbo Yan ${ }^{1}$, Jun Yang ${ }^{1}$, Fei Wang ${ }^{1}$, \\ Lixin $\mathrm{Ma}^{1}{ }^{1}$, Gang $\mathrm{Wu}^{2, *}$ and Chao Zhai ${ }^{1, *}$ \\ 1 State Key Laboratory of Biocatalysis and Enzyme Engineering, School of Life Sciences, Hubei University, \\ Wuhan 430062, China; pengyanhong666@126.com (Y.P.); hewencong@topgenebio.com (W.H.); \\ lu.liu@innoventbio.com (L.L.); dby0525@outlook.com (B.D.); guangbo_yan@126.com (G.Y.); \\ youcojun@outlook.com (J.Y.); wangfei@hubu.edu.cn (F.W.); malixing@hubu.edu.cn (L.M.) \\ 2 Oil Crops Research Institute, Chinese Academy of Agricultural Sciences, Wuhan 430062, China; \\ liyunjing@caas.cn \\ * Correspondence: wugang1976@gmail.com (G.W.); chaozhai@hubu.edu.cn (C.Z.)
}

check for updates

Citation: Peng, Y.; He, W.; Li, Y.; Liu, L.; Deng, B.; Yan, G.; Yang, J.; Wang, F.; Ma, L.; Wu, G.; et al. Degradation of CP4-EPSPS with a Psychrophilic

Bacterium Stenotrophomonas

maltophilia 780. Biomolecules 2022, 12, 318. https://doi.org/10.3390/ biom12020318

Academic Editor: Kyoungwhan Back

Received: 12 January 2022

Accepted: 14 February 2022

Published: 17 February 2022

Publisher's Note: MDPI stays neutral with regard to jurisdictional claims in published maps and institutional affiliations.

Copyright: (C) 2022 by the authors. Licensee MDPI, Basel, Switzerland. This article is an open access article distributed under the terms and conditions of the Creative Commons Attribution (CC BY) license (https:// creativecommons.org/licenses/by/ $4.0 /)$

\begin{abstract}
CP4-EPSPS (Agrobacterium sp. strain CP4 5-enolpyruvylshikimate-3-phosphate synthase) protein showed remarkable thermostability and was highly resistant to proteases, such as trypsin. In order to eliminate the pollution of CP4-EPSPS from the accumulated straws to the surrounding environment during the winter, the present study investigated the extracellular proteases of 21 psychrophilic strains isolated from the south polar region. The results indicated that Stenotrophomonas maltophilia 780 was able to degrade CP4-EPSPS at $18^{\circ} \mathrm{C}$ efficiently. Further study indicated that it was able to grow in the extract of Roundup Ready soybean at $18^{\circ} \mathrm{C}$, with CP4-EPSPS degraded to an undetectable level within $72 \mathrm{~h}$. The extracellular proteases of Stenotrophomonas maltophilia 780 are thermo-sensitive, with an optimal temperature of $65^{\circ} \mathrm{C}$. The genomic sequencing result indicated that this strain had more than a hundred putative protease and peptidase coding genes, which may explain its high capability in decomposing CP4-EPSPS.
\end{abstract}

Keywords: CP4-EPSPS; protease; Stenotrophomonas maltophilia

\section{Introduction}

GM (Genetically Modified) crops have been planted worldwide over the past decades. During 1996 to 2016, the acreage of GE (Genetically Engineered) crops expanded 109-fold. Among them, the crop covering the most hectares globally is soybean. In $2016,78 \%$ of soybeans planted were GE varieties [1]. There are 30 events of transgenic soybeans, and one of the most representative transgenic soybeans is the Roundup Ready soybean (RRS, event GTS40-3-2). The transgenically expressed protein in RRS is CP4-EPSPS protein, a variant of plant 5-enolpyruvyl-shikimate-3-phosphate synthase (EPSPS). Plant EPSPS is involved in the Shikimate pathway, which plays a critical role in many plant functions, such as the production of aromatic amino acids [2,3]. CP4-EPSPS was originally isolated from the soil Agrobacterium sp. strain CP4. The full length of this gene encodes a protein of $55.6 \mathrm{kDa}$, including a 72 aa chloroplast transit peptide and a mature protein of 47.6 kDa. As a variant of plant EPSPS, it has a lower binding affinity to glyphosate [4]. Therefore, constitutive expression of CP4-EPSPS in crops confers increased tolerance to the Roundup family of agricultural herbicides. Except for soybean [5,6], CP4-EPSPS was also applied in transgenic rice [7], cotton (event MON 1445, MON 88913) [8], corn, etc.

Even though the commercial use of GM crops has increased dramatically, the safety of GM plants is still a controversial topic, attracting both the attention of the scientific community and the public. Therefore, the effects of transgenic plants on domestic animals and the environment have been intensively studied [9]. CP4-EPSPS shows no obvious similarity with proteins associated with allergy and toxicity [10], and several investigations 
indicated that doses of CP4-EPSPS much higher than the dietary supplement level had no obvious toxicological effect on the reproductive function in rats [11,12] or animal health as a dietary supplementation [13]. However, some research has still raised possibilities that these plants may cause unintended effects via different pathways, which have to be systematically evaluated. Therefore, any genetically modified plants or animals should undergo strict safety evaluation before entering the food market. Previous studies indicated that CP4EPSPS protein is very stable, and a trace amount of the transgenic protein was still detectable in the highly processed RRS soybean products [14]. Moreover, a higher level of CP4-EPSPS was observed in leaf tissues than in the seeds and roots [10]. To this end, the accumulation of CP4-EPSPS during the returning of straw to the field may cause environmental risks in the long term. In the present study, we screened five isolates with high cold-active protease activity from 21 psychrophilic strains from the south polar region. One of them was able to degrade recombinant CP4-EPSPS efficiently. The molecular taxonomy study indicated that it belonged to Stenotrophomonas maltophilia; hence, it was named S. maltophilia 780. Further study indicated that $S$. maltophilia 780 was able to grow in the extract of Roundup Ready soybean at $18{ }^{\circ} \mathrm{C}$, with CP4-EPSPS degraded to an undetectable level within $72 \mathrm{~h}$. Accordingly, this isolate showed great potential in eliminating the pollution of the CP4-EPSPS protein to the surrounding environment.

\section{Materials and Methods}

\subsection{Bacteria, Plasmids, Media, and Reagents}

E. coli XL10-Gold was obtained from Invitrogen (Carlsbad, CA, USA). E. coli BL21 (DE3) were stored in our lab. All psychrophilic bacteria were obtained from the China Center for Type Culture Collection (CCTCC, Wuhan, China). The geographical sources of the strains are listed in Supplementary Materials Table S1. Vector pET28a was obtained from Novagen, Merck (Darmstadt, Germany). The ORF of CP4-EPSPS was synthesized by Genecreate (Wuhan, China) and cloned into pET28a directly or fused with the coding sequence of $6 \times$ His to generate $\mathrm{N}$ - or C-terminal fusion proteins. The recombinant plasmids were named pET28a-EPSPS, pET28a-His $\times 6$-EPSPS, and pET28a-EPSPS-His $\times 6$, respectively. Luria-Bertani medium (LB) was prepared as described in the Manual of Molecular Cloning. Kanamycin of $50 \mu \mathrm{g} / \mathrm{mL}$ was supplemented before use. $\mathrm{R}_{2} \mathrm{~A}$ media were purchased from Churui (Jiangsu, China), which contained $0.05 \%$ yeast extract, $0.05 \%$ tryptone, $0.05 \%$ casein, $0.05 \%$ glucose, $0.05 \%$ soluble starch, $0.03 \% \mathrm{~K}_{2} \mathrm{HPO}_{4}, 0.0024 \% \mathrm{MgSO}_{4}$, and $0.03 \%$ $\alpha$-ketopropionic acid sodium. Approximately $1.5 \%$ of agar was added for the solid medium. Skimmed milk powder was purchased from BD (USA). Test strips for CP4 EPSPS were obtained from the Institute of Oil Crops, Academy of Agricultural Sciences (Wuhan, China). QualiPlate kit for CP4-EPSPS Corn \& Cotton was purchased from Envirologix (Portland, ME, USA). Trypsin was purchased from Biosharp (Guangzhou, China). All other chemicals were analytical reagents.

\subsection{Expression and Purification of the Recombinant CP4-EPSPS}

The recombinant plasmids pET28a-EPSPS, pET28a-His6-EPSPS, and pET28a-EPSPSHis6 were transformed into E. coli BL21 (DE3) for the expression of recombinant proteins. The recombinant strains expressing CP4-EPSPS were inoculated into $1 \mathrm{~mL}$ of LB media and incubated at $37^{\circ} \mathrm{C}$ and $250 \mathrm{rpm}$ overnight. The starter culture was transferred to $50 \mathrm{~mL}$ of fresh LB media. The mixture was incubated at $37^{\circ} \mathrm{C}$ to $\mathrm{OD}_{600}$ of $0.6-0.8$, and then induced with $0.5 \mathrm{mM}$ of IPTG at $18{ }^{\circ} \mathrm{C}$ for $24 \mathrm{~h}$. Cells were collected and resuspended in lysis buffer (50 mM Tris- $\mathrm{HCl}, 200 \mathrm{mM} \mathrm{NaCl}, 50 \mathrm{mM} \mathrm{NaH}{ }_{2} \mathrm{PO}_{4}, 25 \mathrm{mM}$ imidazole, and 10\% glycerol; $\mathrm{pH}$ 8.0) with lysozyme to a final concentration of $1 \mathrm{mg} / \mathrm{mL}$.

To purify the target protein bearing the $6 \times$ His tag with Ni-NTA resins, the crude cell lysate was applied to Ni-NTA beads for affinity purification. The column was washed twice with two column volumes of the wash buffer $(50 \mathrm{mM}$ Tris- $\mathrm{HCl}, 200 \mathrm{mM} \mathrm{NaCl}$, $50 \mathrm{mM} \mathrm{NaH}{ }_{2} \mathrm{PO}_{4}$, and $40 \mathrm{mM}$ imidazole; $\mathrm{pH}$ 8.0). One column volume of elution buffer (50 mM Tris- $\mathrm{HCl}, 200 \mathrm{mM} \mathrm{NaCl}, 50 \mathrm{mM} \mathrm{NaH}_{2} \mathrm{PO}_{4}$, and $200 \mathrm{mM}$ imidazole; $\mathrm{pH}$ 8.0) was 
used to recover the target protein. The sample was then collected and dialyzed with a Millipore $10 \mathrm{kDa}$ cut-off membrane at $4{ }^{\circ} \mathrm{C}$ to remove ions, salts, and imidazole, followed by resuspension with storage buffer ( $50 \mathrm{~mm}$ Tris- $\mathrm{HCl} ; \mathrm{pH} 7.5)$.

To purify the target protein without an affinity tag, 300-500 $\mu \mathrm{L}$ of the crude cell lysate was loaded on the native gel. The sample was resolved at $90 \mathrm{v}$ until the loading dye reached the bottom of the gel. A slice of the gel (approximately $2 \mathrm{~cm}$ in width) was then cut and stained with the quick staining kit from Beyotime (Shanghai, China). Subsequently, the gel slice containing the target protein was cut from the PAGE gel based on the result of staining and soaked in 300-500 $\mu \mathrm{L}$ of storage buffer for $10-12 \mathrm{~h}$ at $4{ }^{\circ} \mathrm{C}$ to recover the target protein.

\subsection{SDS-PAGE Assay of the Proteins of Interest}

SDS-PAGE was performed on a $12 \%$ running gel. After electrophoresis, the proteins were stained with Coomassie Brilliant Blue R-250. The total protein concentrations of the supernatant were measured using a Bradford kit from Beyotime (Shanghai, China) with bovine serum albumin as the standard.

\subsection{Analyzing the Stability of Recombinant CP4-EPSPS}

To investigate the stability of CP4-EPSPS at room temperature, the recombinant protein was diluted to a final concentration of $2 \mathrm{mg} / \mathrm{mL}$ and incubated at room temperature for a month. Approximately $10 \mu \mathrm{L}$ of the samples was collected every 2 days. Time course monitoring of the stability of CP4-EPSPS to heat was performed with boiling in a water bath or microwaving for more than $2 \mathrm{~h}$.

To study the effect of protease on the stability of CP4-EPSPS, trypsin was added to CP4-EPSPS at a molar ratio of 1:10 and incubated at $\mathrm{pH} 7.0$ for more than $96 \mathrm{~h}$, followed by analysis with SDS-PAGE.

\subsection{Analyzing the Extracellular Protease Activity of the Psychrophilic Bacteria from the South Polar Region}

The psychrophilic bacteria from the polar region were stroked on $1 / 2 R_{2} A$ plates and incubated at $18{ }^{\circ} \mathrm{C}$ for 2-3 days, and then a single colony of each strain was inoculated on $1 / 2 \mathrm{R}_{2} \mathrm{~A}$ plates supplemented with $1 \%$ skimmed milk. The plates were incubated at $18{ }^{\circ} \mathrm{C}$. If the bacteria secreted extracellular proteases, the milk around the colony would be degraded and a clear halo would appear.

\subsection{Digestion of CP4-EPSPS with Extracellular Proteases Generated by Psychrophilic Bacteria}

The psychrophilic bacteria were incubated in $5 \mathrm{~mL}$ of $1 / 2 \mathrm{R}_{2} \mathrm{~A}$ supplemented with $1 \%$ milk for 3-4 days. Approximately $200 \mu \mathrm{L}$ of the culture was centrifuged every $12 \mathrm{~h}$ and the extracellular protease activity in the supernatant was tested on $1 / 2 R_{2} A$ plates supplemented with $1 \%$ skimmed milk until clear halos appeared. Subsequently, the cell culture was centrifuged at $5000 \mathrm{rpm}$ for $5 \mathrm{~min}$ and the supernatant was sterilized with a $0.22 \mu \mathrm{m}$ syringe filter. The filtrate was mixed with CP4-EPSPS at a molar ratio of 1:10 and incubated at $18{ }^{\circ} \mathrm{C}$. The supernatant incubated at $100{ }^{\circ} \mathrm{C}$ for $30 \mathrm{~min}$ was used as the negative control.

\subsection{Isolating a Pure Culture of S. maltophilia 780 and Microscopy Assay}

CCTCC2016780 strain stored in a $-80{ }^{\circ} \mathrm{C}$ freezer was thawed and a loop of cells was resuspended in $100 \mu \mathrm{L}$ of $1 / 2 \mathrm{R}_{2} \mathrm{~A}$ media, followed by 10 -fold serial dilution with $1 / 2 \mathrm{R}_{2} \mathrm{~A}$ media; then $100 \mu \mathrm{L}$ of $10^{5}, 10^{6}$, and $10^{7}$-fold diluted samples were spread on $1 / 2 \mathrm{R}_{2} \mathrm{~A}$ plates and incubated at $18{ }^{\circ} \mathrm{C}$ for $2-3$ days. The petite colonies (S. maltophilia 780) were selected for further experiments. The morphology of the cells was analyzed with Leica microsystems CMS GmbH (Mannheim, Germany) before and after Gram staining. The Gram staining was performed as previously reported. Briefly, a bacterial smear was placed on a slide and then heat-fixed. A drop of crystal violet was added to the sample. Next, the slide was flushed with iodine solution, which fixed the crystal violet to the cell wall, followed by 
washing with ethanol to remove non-fixed crystal violet. The counterstain safranin was added to color the cells red.

\section{8. $16 S$ rDNA Sequence Assay and Genomic Sequencing}

16S rDNA-based taxonomic analysis and the genomic sequencing of S. maltophilia 780 were carried out at Genewiz (Jiangsu, China). The primers used for the amplification of $16 \mathrm{~S}$

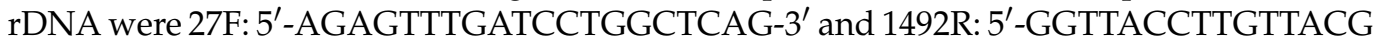
ACTT-3'.

\subsection{Inducing Extracellular Proteases of S. maltophilia 780 with Various Nitrogen Sources}

The bacterial strain was suspended in $1 \mathrm{~mL}$ of $1 / 2 \mathrm{R}_{2} \mathrm{~A}$, and then $100 \mu \mathrm{L}$ of the cell culture was inoculated in $5 \mathrm{~mL}$ of $1 / 2 \mathrm{R}_{2} \mathrm{~A}$ supplemented with $1 \%$ of various nitrogen sources, i.e., milk, trypton, $\left(\mathrm{NH}_{4}\right)_{2} \mathrm{SO}_{4}$, yeast extract, and soybean extract. The samples were incubated at $18{ }^{\circ} \mathrm{C}$ for 3-4 days and the extracellular protease activity was tested on $1 / 2 \mathrm{R}_{2} \mathrm{~A}$ plates supplemented with $1 \%$ skimmed milk.

\subsection{Quantitatively Analyzing the Extracellular Proteases of S. maltophilia 780}

The enzyme activity was measured with casein as a substrate. To study the optimal temperature of the extracellular proteases of $S$. maltophilia $780,1 \mathrm{~mL}$ of a diluted enzyme sample was mixed with an equal volume of $2 \%(w / v)$ casein in $20 \mathrm{~mm}$ phosphate buffer (pH 7.5), followed by incubating at a 0 to $80^{\circ} \mathrm{C}$ gradient with intervals of $10^{\circ} \mathrm{C}$ for $10 \mathrm{~min}$. The reaction was terminated with $2 \mathrm{~mL}$ of $10 \%(w / v)$ trichloroacetic acid (TCA). The mixture was centrifuged at $14,000 \times g$ for $10 \mathrm{~min}$ and the $\mathrm{OD}_{280}$ of the supernatant was measured to determine the amount of L-tyrosine released during the reaction. To study the thermostability of the extracellular proteases of S. maltophilia 780, the diluted enzyme sample was incubated at 25 to $75{ }^{\circ} \mathrm{C}$ with intervals of $10{ }^{\circ} \mathrm{C}$ for $5-30 \mathrm{~min}$, followed by adding an equal volume of $2 \%(w / v)$ casein in $20 \mathrm{mM}$ phosphate buffer ( $\mathrm{pH} 7.5)$, followed by incubating at $25{ }^{\circ} \mathrm{C}$ for $10 \mathrm{~min}$. As mentioned above, the reaction was terminated with TCA and the $\mathrm{OD}_{280}$ was measured. The sample containing the inactivated enzymes (heated at $100{ }^{\circ} \mathrm{C}$ for half an hour) and casein was used as the blank to eliminate the background value caused by the L-tyrosin in the casein. A standard curve was plotted using 0 to $60 \mu \mathrm{g} / \mathrm{mL}$ of L-tyrosin.

To obtain the kinetic parameters for the extracellular proteases of S. maltophilia 780, a pseudo-one-substrate kinetic model was used as described previously [15]. The kinetic parameters were determined from three independent initial rate measurements performed with the same batch of enzyme. The concentration of casein was 0 to $5.0 \mu \mathrm{m}$. The initial rate was measured by the analysis of the produced L-tryosin. The initial rate data were fitted to a Michaelis-Menten equation. The $\mathrm{K}_{\mathrm{M}}$ and $k_{\text {cat }}$ values were calculated from the slope and y intercept of the double reciprocal plot drawing with Original 8.0 software of OriginLab (Northampton, MA, USA).

\subsection{Preparation of Roundup Ready Soybean (RRS) Extract}

RRS was ground and $5 \mathrm{~g}$ of the powder was added to $250 \mathrm{~mL}$ of $\mathrm{dH}_{2} \mathrm{O}$, followed by vigorous stirring for $30 \mathrm{~min}$. The sample was centrifuged at $5000 \mathrm{rpm}$ for $5 \mathrm{~min}$. The supernatant was sterilized by filtration using a $0.22 \mu \mathrm{m}$ filter (Millipore, MA, USA).

\subsection{ELISA}

ELISA was carried out as described in the Manual of QualiPlate kit for CP4-EPSPS Corn \& Cotton (Envirologix, ME, USA). Briefly, $50 \mu \mathrm{L}$ of Roundup Ready enzyme conjugate and $50 \mu \mathrm{L}$ of the sample were added to each well of the plate. The samples were mixed thoroughly, followed by incubating at room temperature for $45 \mathrm{~min}$. The solution in the wells was removed by vigorous shaking and the wells were washed with the wash buffer three times. Equal volumes of the substrate were added to each well and the plate was incubated at room temperature for $15 \mathrm{~min}$, followed by adding $100 \mu \mathrm{L}$ of the stop solution 
to each well. The result was read with a multi-mode microplate reader (SpectraMax, CA, USA) at a wavelength of $450 \mathrm{~nm}$.

\section{Results}

\subsection{Recombinant Expression of CP4-EPSPS}

E. coli BL21 (DE3) bearing pET28a-EPSPS, pET28a-His6-EPSPS, and pET28a-EPSPSHis6 were used to express the recombinant proteins. The ORF of CP4-EPSPS is $1623 \mathrm{bp}$ (Genbank accession No. NP_740524, Supplementary Materials Figure S1) and encodes a protein of approximately $47 \mathrm{kDa}$. The result of SDS-PAGE indicated that a band consistent with the predicted size of CP4-EPSPS was detected in the supernatant of the cell lysate (Figure 1a). The target proteins bearing $6 \times$ His tags were purified with Ni-NTA. Meanwhile, the recombinant CP4-EPSPS without a fusion tag was purified with native gel. The result of SDS-PAGE indicated that all of them were purified successfully (Figure 1b-d).

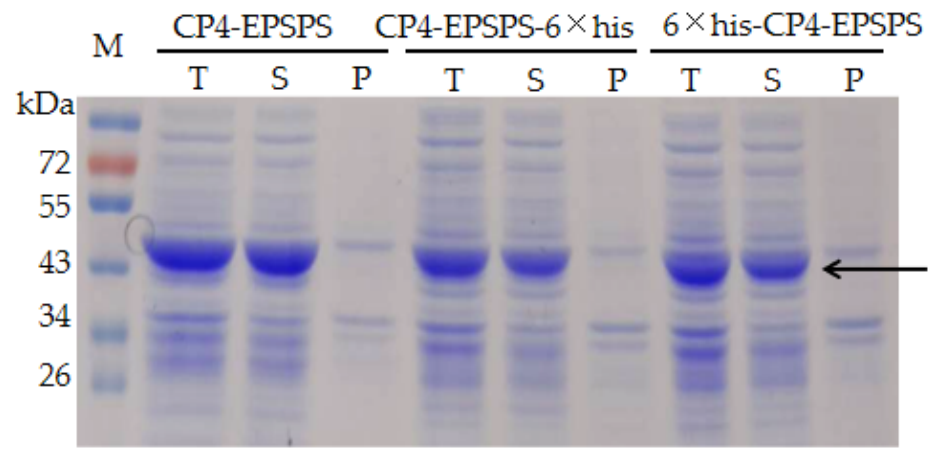

(a)

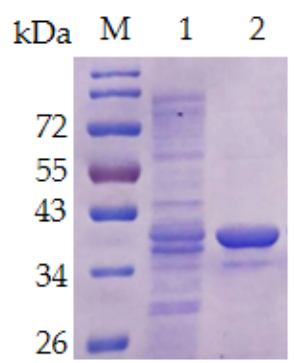

(b)

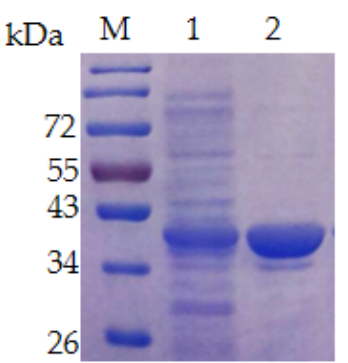

(c)

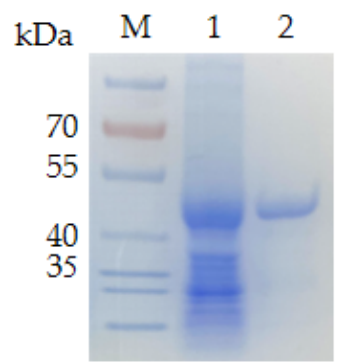

(d)

Figure 1. Expression and purification of recombinant CP4-EPSPS protein. (a) Expression of recombinant CP4-EPSPS with E. coli BL21 (DE3) as a host. T: total protein of the cells; S: supernatant of the cell lysate; P: pellet of the cell lysate. The target protein is indicated with an arrow. (b) Purified $6 \times$ his-CP4-EPSPS; (c) purified CP4-EPSPS- $6 \times$ his; (d) purified CP4-EPSPS. Lane 1: supernatant of the cell lysate; Lane 2: purified target protein; M: protein molecular weight marker (the size of each band is indicated on the left).

\subsection{Stability of the Recombinant CP4-EPSPS}

To investigate the stability of CP4-EPSPS, the recombinant protein was diluted to $2 \mathrm{mg} / \mathrm{mL}$ and incubated at room temperature. The result of SDS-PAGE indicated that no obvious degradation of the target protein was detected in 25 days (Figure 2a). The three forms of recombinant proteins were also boiled in a water bath and no obvious degradation of the target protein was detected after $1.5 \mathrm{~h}$ of heating (Figure $2 \mathrm{~b}$ ). In addition, the target protein remained soluble after $30 \mathrm{~min}$ of microwaving (Figure 2c). These results indicated that CP4-EPSPS was highly resistant to heat. To investigate the effect of protease on CP4-EPSPS, commercial trypsin was used to digest CP4-EPSPS. The result indicated 
that CP4-EPSPS was resistant to high concentrations of trypsin. It took $96 \mathrm{~h}$ for trypsin to degrade CP4-EPSPS completely at a molar ratio of 1:10 (Figure 3).

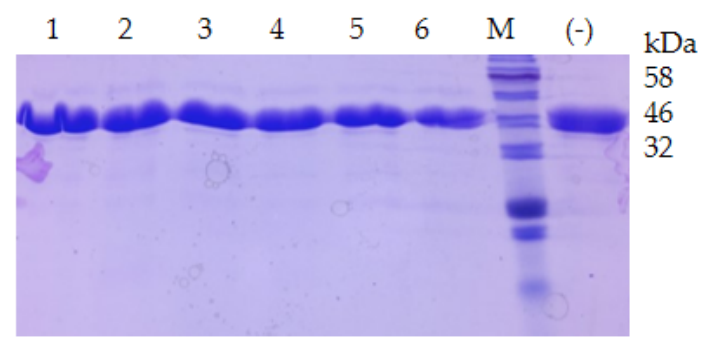

(a)

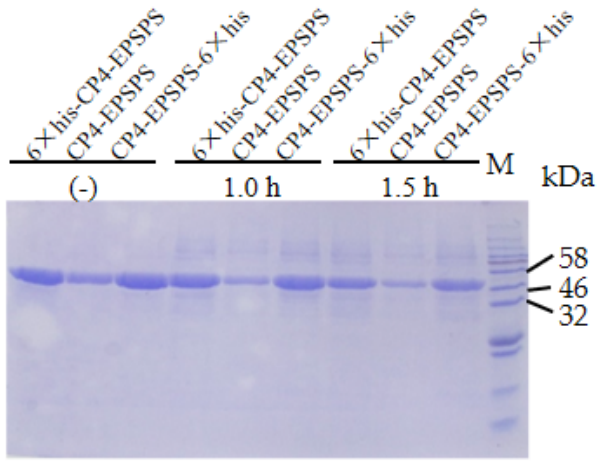

(b)

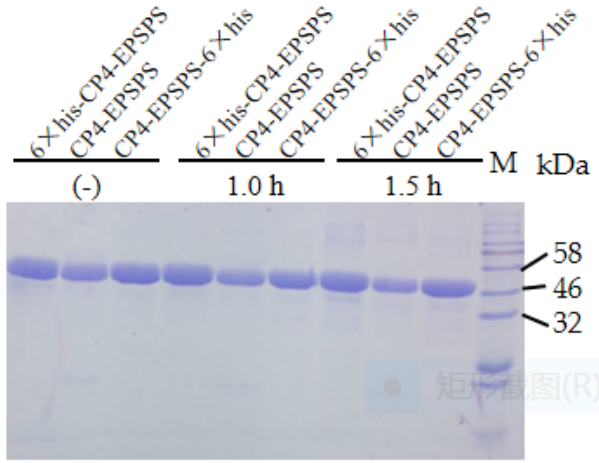

(c)

Figure 2. Stability of the recombinant CP4-EPSPS. (a) Stability of the recombinant CP4-EPSPS at room temperature. Lane 1-6: recombinant $6 \times$ his-CP4-EPSPS incubated at room temperature for 1, 2, 4, 7, 15 , and 25 days, respectively; (-) the negative control. (b) Stability of the recombinant CP4-EPSPS with boiling. (c) Stability of the recombinant CP4-EPSPS with microwaving; M, protein molecular weight marker (the size of each band is indicated on the right).

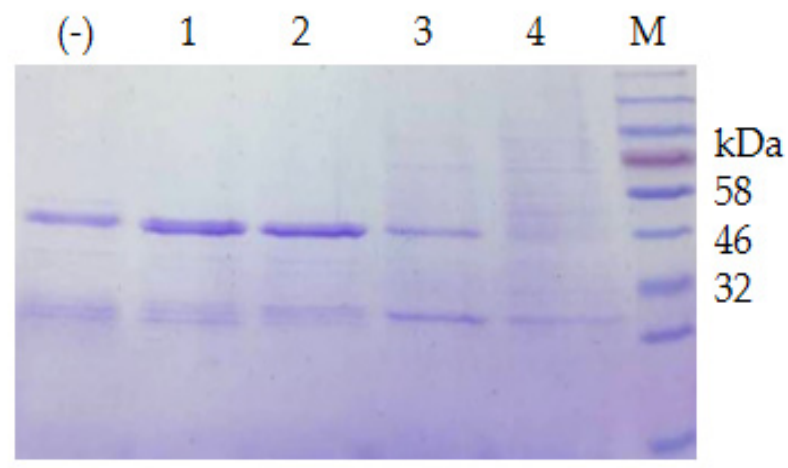

Figure 3. Digestion of CP4-EPSPS with trypsin. Lane 1-4: digestion of $6 \times$ his-CP4-EPSPS with trypsin at a molar ratio of 10:1 for 12,24, 84, and $96 \mathrm{~h}$, respectively; (-) the negative control; M, protein molecular weight marker (the size of each band is indicated on the right).

\subsection{Screening Psychrophilic Bacteria Strains Capable of Degrading the Recombinant CP4-EPSPS}

Twenty-one psychrophilic bacterial strains isolated from the south polar region (Supplementary Materials Table S1) were inoculated on $\frac{1}{2} \mathrm{R}_{2}$ A plates supplemented with $1 \%$ milk and incubated at $18{ }^{\circ} \mathrm{C}$. Clear halos appeared around the colonies of CCTCC2016780, 741, 742, 743, and 808, while a relatively small halo formed around CCTCC2016809 after 3 days (Figure 4 ), which indicated that these strains secreted cold-active proteases to the surrounding environment. The experiment was run in triplicate. CCTCC2016780, 741, 742, 
743, and 808 exhibited robust extracellular protease activities and clear halos were formed in all three repeats. These strains were incubated in $1 / 2 \mathrm{R}_{2} \mathrm{~A}$ supplemented with $1 \%$ milk for 3 days. The supernatants of the cell cultures were gathered and incubated with the recombinant CP4-EPSPS. After $48 \mathrm{~h}$ of digestion, proteases secreted by CCTCC2016780 and 808 showed obvious degradation of CP4-EPSPS and the band of CP4-EPSPS almost disappeared. The extracellular proteases of CCTCC2016741 and 742 were also capable of degrading CP4-EPSPS and the target protein was partially digested. On the contrary, CCTCC2016809 exhibited no obvious effect on CP4-EPSPS (Figure 5). Since CCTCC2016780 demonstrated the most obvious effect, it was used for further study.
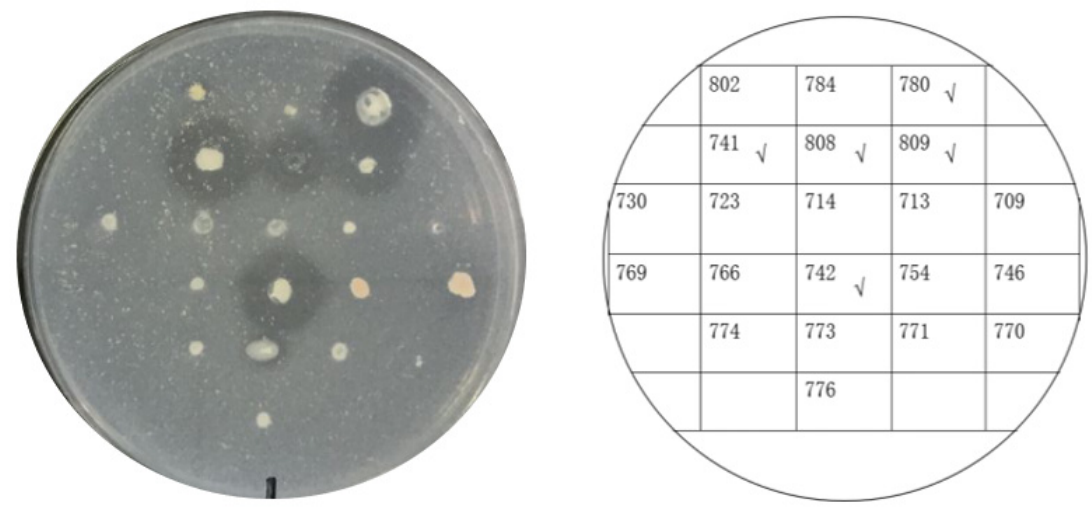

Figure 4. Screening psychrophilic bacterial strains with extracellular protease activity. The serial number of each strain is indicated on the right. Strains with obvious extracellular protease activity are ticked.

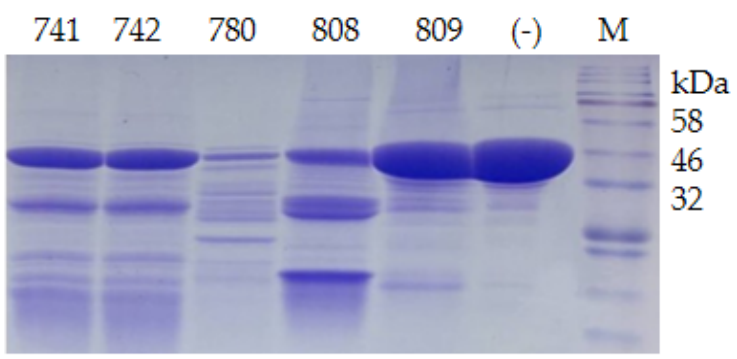

Figure 5. Degradation of recombinant CP4-EPSPS with extracellular proteases of psychrophilic bacterial strains. The serial number of each strain is indicated on the SDS-PAGE gel; (-) the negative control; M, protein molecular weight marker (the size of each band is indicated on the right).

\subsection{Identification of Psychrophilic Bacteria CCTCC2016780}

According to the molecular taxonomy result of CCTCC, CCTCC2016780 belongs to Mucilaginibacter gotjawali (Supplementary Materials Table S1). During the process of obtaining a pure culture, we realized that this isolate was composed of two strains. Both strains formed white colonies on $1 / 2 \mathrm{R}_{2} \mathrm{~A}$ plates after $48 \mathrm{~h}$ of incubation at $18{ }^{\circ} \mathrm{C}$ (Figure 6). Both strains were identified by $16 \mathrm{~S}$ rDNA sequence analysis. The strain that showed robust growth was identified as Pseudomonas sp., since its 16S rDNA had 100\% identity with Pseudomonas moraviensis WTB8 and Pseudomonas sp. PS13 (Supplementary Materials Figure S2). The 16S rDNA of the petite colonies showed 99\% identity with Stenotrophomonas maltophilia 7K14 and R551-3, which suggested that it belonged to Stenotrophomonas maltophilia (Supplementary Materials Figure S3). Accordingly, these two strains were named Pseudomonas sp. 780 and S. maltophilia 780, respectively. 


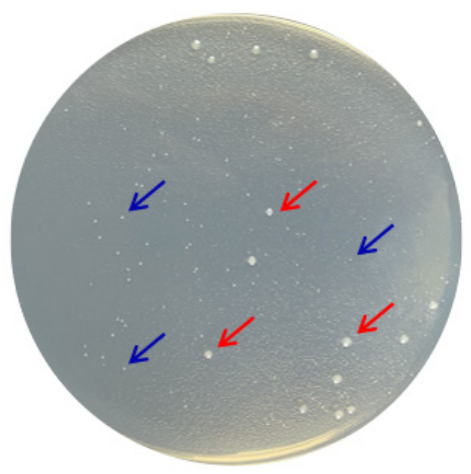

Figure 6. Two bacterial strains isolated from Mucilaginibacter gotjawali 780. The red arrows indicate Pseudomonas sp. 780 with robust growth and the blue arrows indicate S. maltophilia 780 , which formed petite colonies.

The extracellular proteases of both strains were induced with milk and utilized for the degradation of the recombinant CP4-EPSPS. The result of SDS-PAGE indicated that the extracellular proteases of S. maltophilia 780 degraded CP4-EPSPS efficiently, and almost all CP4-EPSPS was degraded in $5 \mathrm{~h}$ (Figure 7). On the contrary, the extracellular proteases of P. sp. 780 had no effect on the target protein (Supplementary Materials Figure S4). Therefore, S. maltophilia 780 was used for further study.

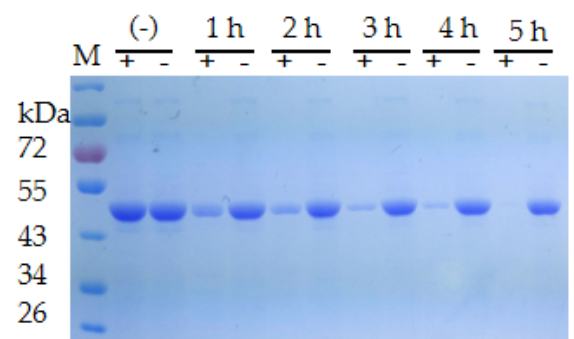

(a)

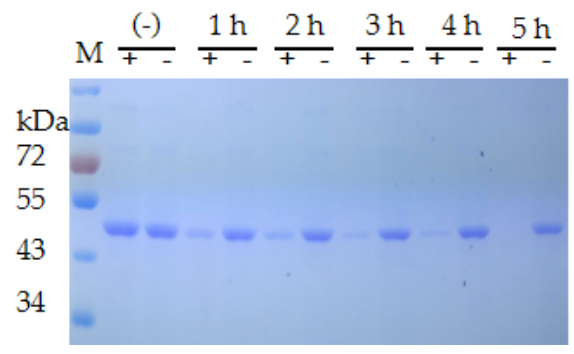

(b)

Figure 7. Time course of the degradation of recombinant CP4-EPSPS with the extracellular proteases of S. maltophilia 780. (a) Degradation of $6 \times$ HIS-CP4-EPSPS; (b) degradation of CP4-EPSPS-6 $\times$ HIS; $(-)$ the negative control (degradation with supernatant of cell culture heated at $100{ }^{\circ} \mathrm{C}$ for $30 \mathrm{~min}$ ); $\mathrm{M}$, protein molecular weight marker (the size of each band is indicated on the left).

The morphological study indicated that $S$. maltophilia 780 was Gram negative and had a short rod shape (Figure 8), which is consistent with the typical features of S. maltophilia. As a psychrophilic bacterium, S. maltophilia 780 showed obvious growth at $18{ }^{\circ} \mathrm{C}$, while its growth was completely inhibited at $37^{\circ} \mathrm{C}$ in both $1 / 2 \mathrm{R}_{2} \mathrm{~A}$ and $\mathrm{LB}$ media.

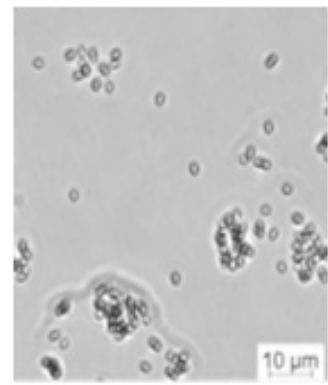

(a) (b)

Figure 8. Microscopic examination of S. maltophilia 780. (a) DIC (digital image correlation) with Leica microsystems CMS GmbH; (b) Gram staining. 


\subsection{Characteristics of the Extracellular Proteases of S. maltophilia 780}

The effect of various nitrogen sources on the biosynthesis of extracellular proteases of S. maltophilia 780 was investigated. The organic nitrogen sources had stronger inducing effects than simple nitrogen sources, such as $\left(\mathrm{NH}_{4}\right)_{2} \mathrm{SO}_{4}$. Among the organic nitrogen sources, milk demonstrated the most obvious effect (Figure 9). Because S. maltophilia 780 is a psychrophilic bacteria, its extracellular proteases had weak activity at $0{ }^{\circ} \mathrm{C}$ and the activity increased with the elevation of the temperature (Figure 10a). It is puzzling that the activity reached the maximum level at $65^{\circ} \mathrm{C}$, which was relatively high in comparison with other psychrophiles. Consistent with the features of cold-active enzymes, the extracellular proteases of S. maltophilia 780 were sensitive to heat and most of the activity was lost at $70{ }^{\circ} \mathrm{C}$ in $10 \mathrm{~min}$. On the other hand, they were relatively stable at $25^{\circ} \mathrm{C}$ and retained approximately $80 \%$ of the activity after $30 \mathrm{~min}$ (Figure $10 \mathrm{~b}$ ). The kinetic parameters of the extracellular proteases of $S$. maltophilia 780 were investigated. The binding affinity $\left(K_{\mathrm{M}}\right)$ was $767.08 \mu \mathrm{m}$. On the contrary, the catalytic turnover $\left(k_{c a t}\right)$ was $1.39 \times 10^{3} \mathrm{~s}^{-1}$ (Figure 10c).

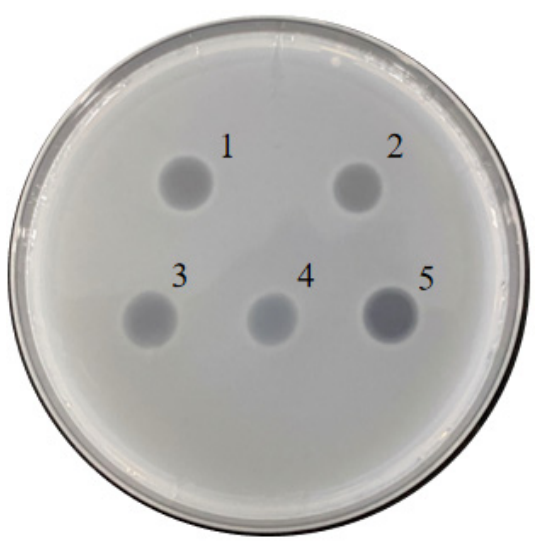

Figure 9. Extracellular protease generated by S. maltophilia 780 induced with different nitrogen sources. 1: extract of Roundup Ready soybean powder; 2 : $1 \%$ yeast extract; 3 : $1 \%$ trypton; 4 : $1 \%$ $\left(\mathrm{NH}_{4}\right)_{2} \mathrm{SO}_{4} ; 5: 1 \%$ milk powder.

\subsection{Degradation of CP4-EPSPS in RRS with S. maltophilia 780a}

S. maltophilia 780 was incubated in $1 / 2 \mathrm{R}_{2} \mathrm{~A}$ supplemented with $1 \%$ milk for 3 days, and the supernatant was applied to degrade CP4-EPSPS in RRS extract. The result of the test strips indicated that the concentration of CP4-EPSPS decreased to an undetectable level after $30 \mathrm{~h}$ of incubation (Figure 11). As the culture of S. maltophilia 780 could degrade CP4-EPSPS in the transgenic soybean efficiently, this isolate was cultivated in the extract of RRS directly. The result indicated that $S$. maltophilia 780 was able to grow in the extract of RRS, while E. coli DH5 $\alpha$ grew much slower (Figure 12a). Meanwhile, ELISA indicated that CP4-EPSPS in the extract was degraded to an almost undetectable level after approximately $72 \mathrm{~h}$. On the other hand, E. coli DH5 $\alpha$ had no obvious effect (Figure 12b).

\subsection{Genomic Sequencing of S. maltophilia 780 and the Genes Encoding Proteases}

The general genomic features of S. maltophilia 780 are listed in Table 1. The G + C content of S. maltophilia 780 was $64.58 \%$, which was consistent with that of other S. maltophilia genomes. The genome size of $S$. maltophilia 780 , slightly larger than the previously reported S. maltophilia genomes, was approximately $5.77 \mathrm{Mb}$ with 5536 predicated CDS [16]. Functional annotation indicated that more than a hundred genes coded proteases and peptidases (Supplementary Materials Table S2). 


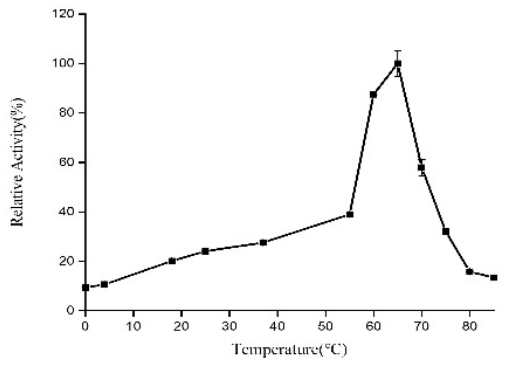

(a)

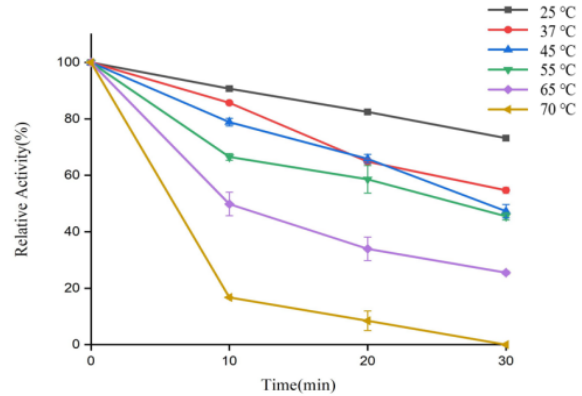

(b)

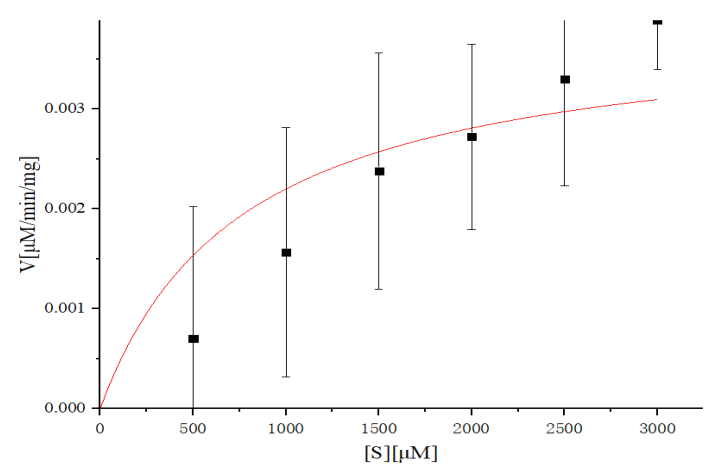

(c)

Figure 10. Effect of temperature on the activity and stability of the extracellular proteases of $S$. maltophilia 780. (a) Optimum temperature of the enzymes; (b) effect of temperature on the thermostability of the enzymes; (c) kinetic analysis of the extracellular proteases of S. maltophilia 780.

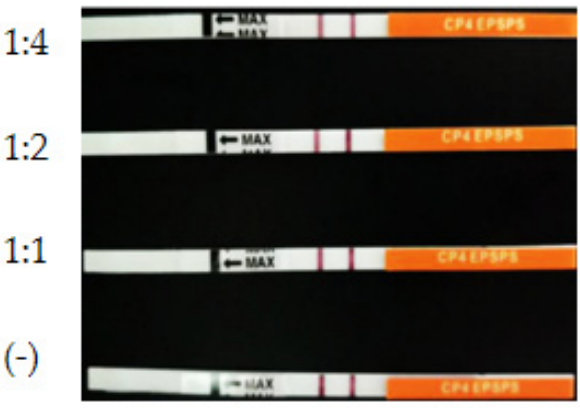

(a)

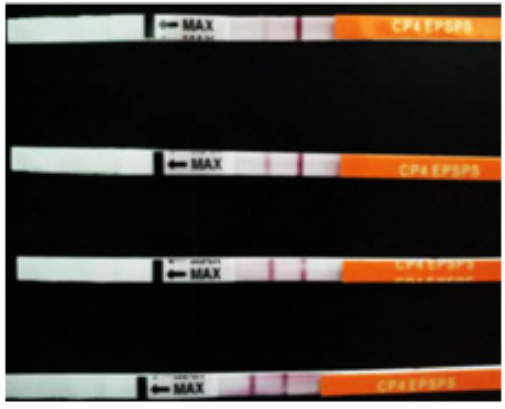

(b)

Figure 11. Time course of the degradation of CP4-EPSPS in the extract of RRS using the cell culture of S. maltophilia 780. (a) RRS extract incubated with inactivated enzymes (negative controls). (b) RRS extract incubated with the enzymes. The ratio of the extract to the enzymes $(v / v)$ is indicated on the left of the figure.

Table 1. Genomic features of S. maltophilia 780.

\begin{tabular}{cc}
\hline Feature & Value \\
\hline Genome size $/ \mathrm{Mb}$ & 5.77 \\
$\mathrm{G}+$ C content $/ \%$ & $64.58 \%$ \\
Protein-coding genes (CDS) & 5536 \\
rRNA (5S, 16S, 23S) & 3 \\
tRNA & 55 \\
Other ncRNA & 54 \\
\hline
\end{tabular}




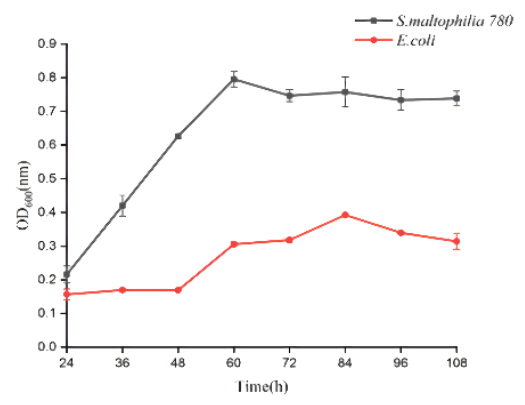

(a)

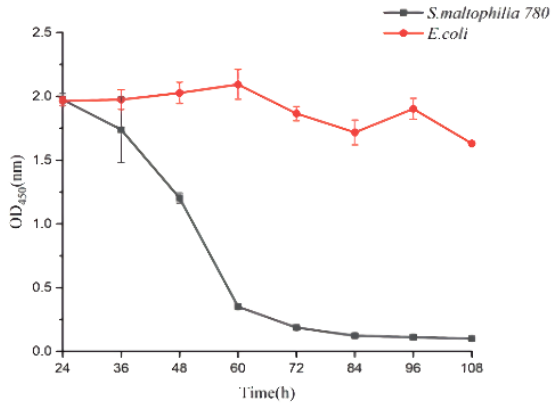

(b)

Figure 12. Degradation of CP4-EPSPS in the extract of RRS during the growth of S. maltophilia 780. (a) Growth curve of E. coli and S. maltophilia 780 in the extract of RRS. (b) CP4-EPSPS level in the cell culture.

\section{Discussions}

Psychrophiles are defined as organisms having an optimal temperature for growth of $15^{\circ} \mathrm{C}$ or lower and a maximum temperature for growth of about $20^{\circ} \mathrm{C}$ [17]. Psychrophiles thrive in the cold environments on Earth and provide a rich source of cold-active enzymes, which display high catalytic activity at low temperatures in comparison with their mesophilic counterparts. These enzymes play important roles in psychrophiles to cope with low temperatures [18]. Recently, many psychrophiles have been screened and applied in bioremediation $[19,20]$, and their cold-active enzymes, such as lipase, amylase, cellulase, protease, etc., have also been widely applied in the pharmaceutical, food, and detergent industries [21,22]. Previous reports and the present study indicated that CP4-EPSPS is remarkably stable. After GM crops, such as soybean, rice, etc., are harvested, the straw is returned to the field. During the decomposition of the straw in the autumn and winter, CP4-EPSPS accumulates in the soil. To accelerate the degradation of CP4-EPSPS in soil under low temperatures, we screened bacteria with high cold-active proteases from psychrophilic bacteria. Among them, S. maltophilia 780 showed the most obvious effect on decomposing CP4-EPSPS. Previous studies on S. maltophilia focused mainly on the comparative genomics [23] and the mechanisms of antibiotic resistance, because some S. maltophilia isolated from hospital settings are emerging nosocomial pathogens with multi-drug resistance [24]. However, S. maltophilia have been widely discovered in various environments, including water, soil, and especially the rhizosphere. S. maltophilia in the rhizosphere promote the growth of plants and protect them against fungal and bacterial pathogens [25]. Some S. maltophilia also contribute to bioremediation and phytoremediation [26,27]. Therefore, they display great potential for agricultural and industrial applications. In the present study, we discovered that the extracellular enzymes synthesized by S. maltophilia 780 are able to degrade CP4-EPSPS efficiently. Meanwhile, as an Antarctic psychrophile, S. maltophilia 780 grows at $18{ }^{\circ} \mathrm{C}$, but is inhibited at $37^{\circ} \mathrm{C}$; hence it might be safe for human health, but this needs further investigation. Therefore, it is possible to supply this isolate to composite microbial fertilizer to eliminate the pollution of CP4-EPSPS in the soil during the autumn and winter; in turn, the robust protease activity of this isolate could convert proteins and peptides in the soil to small molecules and promote the growth of crops in the next year.

The proteases derived from Antarctic organisms have attracted worldwide attention due to their high catalytic activity at low temperatures $[15,28,29]$. Similar to these coldactive proteases, the extracellular proteases of S. maltophilia 780 are thermo-sensitive [30-32]. The enzymes lost more than $50 \%$ of their activity at $45-75{ }^{\circ} \mathrm{C}$ for $30 \mathrm{~min}$. On the other hand, the proteases produced by psychrophilic bacteria are not fully adapted to work in cold environments. The activity of their proteases is temperature dependent, which is similar to their mesophilic counterparts. Their proteolytic activity is almost negligible at the temperature of the environment where the producing strains live. Psychrophilic bacteria 
turn to produce more enzymes to make up for the loss of activity at low temperatures, rather than increase the activity of the enzymes under low temperatures. Therefore, it is common that the optimal temperatures of proteases reach $40-55{ }^{\circ} \mathrm{C}$ [28]. However, the extracellular proteases of $S$. maltophilia 780 exhibited an optimal temperature of $65^{\circ} \mathrm{C}$, which is higher than that in previous reports. We deduced that there were multiple proteases in S. maltophilia 780. Consistent with this result, the gene annotation of S. maltophilia 780 indicated that there are more than a hundred putative proteases and peptidases in S. maltophilia 780, and more proteases may be found in the hypothetical proteins, which rend the gene mining of the proteases responding to the decomposition of CP4-EPSPS a huge challenge. Moreover, the degradation of CP4-EPSPS may be caused by the cooperation of several proteases. For this reason, certain proteases that catalyze the degradation of CP4-EPSPS were not detected in the present study.

In summary, we screened a psychrophile, S. maltophilia 780, for the efficient degradation of CP4-EPSPS, which may provide a powerful tool to solve the pollution of transgenic proteins in the natural environment.

Supplementary Materials: The following supporting information can be downloaded at: https: / / www.mdpi.com/article/10.3390/biom12020318/s1, Figure S1: Sequence of CP4-EPSPS; Table S1: strains obtained from CCTCC; Figure S2: $16 \mathrm{~S}$ rDNA alignment of P. sp. 780; Figure S3: 16S rDNA alignment of S. maltophilia 780; Figure S4: Time course of the degradation of the recombinant CP4EPSPS with extracellular proteases of P. sp. 780; Table S2: The putative ORFs coding proteases and peptidases in S. maltophilia 780.

Author Contributions: Conceptualization, G.W. and C.Z.; methodology, Y.P.; software, Y.P. and W.H.; validation, G.W. and C.Z.; formal analysis, Y.P.; investigation, W.H., B.D., G.Y., J.Y. and L.L.; resources, Y.L.; data curation, Y.P.; writing—original draft preparation, Y.P.; writing—review and editing, C.Z.; visualization, F.W.; supervision, L.M. and C.Z; project administration, G.W.; funding acquisition, G.W. All authors have read and agreed to the published version of the manuscript.

Funding: This work was supported by the National Major Special Project of Breeding for Genetically Modified Organisms in China research and development program of China (No. 2016X08012-005).

Institutional Review Board Statement: Not applicable.

Informed Consent Statement: Informed consent was obtained from all subjects involved in the study.

Data Availability Statement: Not applicable.

Conflicts of Interest: The authors declare no conflict of interest.

\section{References}

1. ISAAA. Global Status of Commercialized Biotech/GM Crops; ISAAA: Ithaca, NY, USA, 2016; Volume 52.

2. Steinrücken, H.C.; Amrhein, N. The herbicide glyphosate is a potent inhibitor of 5-enolpyruvyl-shikimic acid-3-phosphate synthase. Biochem. Biophys. Res. Commun. 1980, 94, 1207-1212. [CrossRef]

3. Hoagland, R.E.; Jordan, R.H.; Teaster, N.D. Bioassay and Characterization of Several Palmer Amaranth (Amaranthus palmeri) Biotypes with Varying Tolerances to Glyphosate. Am. J. Plant Sci. 2013, 4, 1029-1037. [CrossRef]

4. Barry, G.; Kishore, G.; Padgette, S. Inhibitors of amino acid biosynthesis: Strategies for imparting glyphosate tolerance to crop plants. Curr. Top. Plant Physiol. 1992, 7, 139-145.

5. Padgette, S.R.; Kolacz, K.H.; Delannay, X. Development, identification, and characterization of a glyphosate-tolerant soybean line. Crop Sci. 1995, 35, 1451-1461. [CrossRef]

6. Howe, A.R.; Gasser, C.S.; Brown, S.M. Glyphosate as a selective agent for the production of fertile transgenic. Mol. Breed. 2002, 10, 153-164. [CrossRef]

7. Chhapekar, S.; Raghavendrarao, S.; Pavan, G.; Ramakrishna, C.; Singh, V.K.; Phanindra, M.L.; Dhandapani, G.; Sreevathsa, R.; Ananda Kumar, P. Transgenic rice expressing a codon-modified synthetic CP4-EPSPS confers tolerance to broad-spectrum herbicide, glyphosate. Plant Cell Rep. 2015, 34, 721-731. [CrossRef]

8. Cerny, R.E.; Bookout, J.T.; CaJacob, C.A.; Groat, J.R.; Hart, J.L.; Heck, G.R.; Huber, S.A.; Listello, J.; Martens, A.B.; Oppenhuizen, M.E.; et al. Development and Characterization of a Cotton (Gossypium hirsutum L.) Event with Enhanced Reproductive Resistance to Glyphosate. Crop Sci. 2010, 50, 1375-1384. [CrossRef]

9. Marvier, M.; Van Acker, R.C. Can crop transgenes be kept on a leash? Front. Ecol. Environ. 2005, 3, 99-106. [CrossRef] 
10. Chinnadurai, P.; Stojšin, D.; Liu, K.; Frierdich, G.E.; Glenn, K.C.; Geng, T.; Schapaugh, A.; Huang, K.; Deffenbaugh, A.E.; Liu, Z.L.; et al. Variability of CP4 EPSPS expression in genetically engineered soybean (Glycine max L. Merrill). Transgenic Res. 2018, 27, 511-524. [CrossRef]

11. Shi, Z.; Zou, S.; Lu, C.; Wu, B.; Huang, K.; Zhao, C.; He, X. Evaluation of the effects of feeding glyphosate-tolerant soybeans (CP4 EPSPS) on the testis of male Sprague-Dawley rats. GM Crop. Food 2019, 10, 181-190. [CrossRef] [PubMed]

12. Ali, Q.; Salisu, I.B.; Shahid, A.A.; Liaqat, A.; Rao, A.Q. A 90-day subchronic toxicity study of transgenic cotton expressing Cry1Ac, Cry2A and CP4-EPSPS proteins in Sprague-Dawley rats. Food Chem. Toxicol. 2020, 146, 111783. [CrossRef] [PubMed]

13. Salisu, I.B.; Shahid, A.A.; Yaqoob, A.; Rao, A.Q.; Husnain, T. Effect of dietary supplementation of recombinant Cry and Cp4 epsps proteins on haematological indices of growing rabbits. J. Anim. Physiol. Anim. Nutr. 2019, 103, 305-316. [CrossRef] [PubMed]

14. Wu, H.; Wang, X.; Zhou, X.; Zhang, Y.; Huang, M.; He, J.; Shen, W. Targeting the middle region of CP4-EPSPS protein for its traceability in highly processed soy-related products. Food Sci. Technol. 2017, 54, 3142-3151. [CrossRef] [PubMed]

15. Alam, S.I.; Dube, S.; Reddy, G.S.N.; Bhattacharya, B.K.; Shivaji, S.; Singh, L. Purification and characterisation of extracellular protease produced by Clostridium sp. from Schirmacher oasis, Antarctica. Enzym. Microb. Technol. 2005, 36, 824-831. [CrossRef]

16. Ragupathi, N.K.D.; Veeraraghava, B. Data on whole genome shotgun sequencing report of clinical S. maltophilia strains from India. Data Brief 2018, 21, 263-268. [CrossRef]

17. Morita, R.Y. Psychrophilic bacteria. Bacteriol. Rev. 1975, 39, 144-167. [CrossRef]

18. Collins, T.; Margesin, R. Psychrophilic lifestyles: Mechanisms of adaption and biotechnological tools. Appl. Microbiol. Biotechnol. 2019, 103, 2857-2871. [CrossRef]

19. Aislabie, J.; Saul, D.J.; Foght, J.M. Bioremediation of hydrocarbon-contaminated polar soils. J. Extrem. 2006, 10, 171-179. [CrossRef]

20. Lin, X.; Yang, B.; Shen, J.; Du, N. Biodegradation of crude oil by an Arctic psychrotrophic bacterium Pseudoalteromomas sp. P29. Curr. Microbiol. 2009, 59, 341-345. [CrossRef]

21. Maiangwa, J.; Ali, M.S.; Salleh, A.B.; Rahman, R.N.; Shariff, F.M.; Leow, T.C. Adaptational properties and applications of cold-active lipases from psychrophilic bacteria. Extremophiles 2015, 19, 235-247. [CrossRef] [PubMed]

22. Cavicchioli, R.; Siddiqui, K.S.; Andrews, D.; Sowers, K.R. Low-temperature extremophiles and their applications. Curr. Opin. Biotechnol. 2002, 13, 253-261. [CrossRef]

23. Youenou, B.; Favre-Bonté, S.; Bodilis, J.; Brothier, E.; Dubost, A.; Muller, D.; Nazaret, S. Comparative Genomics of Environmental and Clinical Stenotrophomonas maltophilia Strains with Different Antibiotic Resistance Profiles. Genome Biol. Evolut. 2015, 7, 2484-2505. [CrossRef]

24. Falagas, M.E.; Kastoris, A.C.; Vouloumanou, E.K.; Dimopoulos, G. Community-acquired Stenotrophomonas maltophilia infections: A systematic review. Eur. J. Clin. Microbiol. Infect. Dis. 2009, 28, 719-730. [CrossRef] [PubMed]

25. Ryan, R.P.; Monchy, S.; Cardinale, M.; Taghavi, S.; Crossman, L.; Avison, M.B.; Berg, G.; van der Lelie, D.; Dow, J.M. The versatility and adaptation of bacteria from the genus Stenotrophomonas. Nat. Rev. Microbiol. 2009, 7, 514-525. [CrossRef] [PubMed]

26. Pages, D.; Rose, J.; Conrod, S.; Cuine, S.; Carrier, P.; Heulin, T.; Achouak, W. Heavy metal tolerance in Stenotrophomonas maltophilia. PLoS ONE 2008, 3, e1539. [CrossRef]

27. Antonioli, P.; Lampis, S.; Chesini, I.; Vallini, G.; Rinalducci, S.; Zolla, L.; Righetti, P.G. A new bacterial strain suitable for bioremediation of selenite-contaminated environmental matrices. Appl. Environ. Microbiol. 2007, 73, 6854-6863. [CrossRef]

28. Vázquez, S.C.; Hernández, E.; Cormack, W.P.M. Extracellular proteases from the Antarctic marine Pseudoalteromonas sp. P96-47 strain. Rev. Argent. Microbiol. 2008, 40, 63-71.

29. Zhou, M.Y.; Wang, G.L.; Li, D.; Zhao, D.L.; Qin, Q.L.; Chen, X.L.; Chen, B.; Zhou, B.C.; Zhang, X.Y.; Zhang, Y.Z. Diversity of both the cultivable protease-producing bacteria and bacterial extracellular proteases in the coastal sediments of King George Island, Antarctica. PLoS ONE 2013, 8, e79668. [CrossRef]

30. Run, Y.; Zeng, R.; Zhang, J.; Zhao, N.W. Cold-active serine alkaline protease from the psychrophilic bacterium Pseudomonas strain DY-A: Enzyme purification and characterization. Extremophiles 2003, 7, 335-337.

31. Kulakova, L. Cold-active serine alkaline protease from the psychrotrophic bacterium Shewanella strain ac10: Gene cloning and enzyme purification and characterization. Appl. Environ. Microbiol. 1999, 65, 611. [CrossRef] [PubMed]

32. Morita, Y.; Hasan, Q.; Sakaguchi, T. Properties of a cold-active protease from psychrotrophic Flavobacterium balustinum P104. Appl. Microbiol. Biotechnol. 1998, 50, 669-675. [CrossRef] [PubMed] 